\title{
HUBUNGAN KEBIASAAN MEROKOK DI DALAM RUMAH DENGAN KEJADIAN ISPA PADA ANAK BALITA 0-5 TAHUN DI PUSKESMAS BUKIT SANGKAL PALEMBANG 2019
}

\author{
Fera Siska \\ Program Studi DIII Keperawatan STIKES Mitra Adiguna Palembang \\ Komplek Kenten Permai Blok J No.9-12 Bukit Sangkal Palembang 30114 \\ Email : feesiska@gmail.com
}

\begin{abstract}
Abstrak
Menurut World Health Organization (WHO) memperkirakan insidens Infeksi Saluran Pernapasan Akut (ISPA) di negara berkembang dengan angka kematian balita di atas 40 per 1000 kelahiran hidup. Asap rokok sebagai salah satu resiko timbulnya ISPA merupakan masalah yang sangat sulit untuk di minimalisir. Tujuan penelitian untuk mengetahui hubungan kebiasaan merokok di dalam rumah dengan kejadian ISPA pada anak balita 0-5 tahun di Puskesmas Bukit Sangkal Palembang tahun 2019. Metode penelitian yang digunakan adalah metode kuantitatif dengan pendekatan analitik cross sectional. Populasi semua ibu yang membawa anak usia 0-5 tahun ke Puskesmas Bukit Sangkal Palembang dengan jumlah sampel sebanyak 30 responden. Hasil penelitian didapatkan distribusi frekuensi responden yang dinyatakan menderita ISPA sebanyak 11 responden (36,7\%) dan responden yang anggota keluarganya merokok sebanyak 17 responden (56,7\%). Hasil uji statistik didapatkan ada hubungan yang bermakna antara kebiasaan merokok dengan kejadian ISPA pada balita di Puskesmas Bukit Sangkal Palembang Tahun 2019 dengan $p$ value $=0,007<\alpha(0,05)$ dan nilai OR $=17,143$. Saran penelitian diharapkan pihak puskesmas dapat meningkatkan penyuluhan kesehatan secara rutin kepada masyarakat tentang bagaimana cara mencegah dan menanggulangi penyakit ISPA di masyarakat.
\end{abstract}

Kata Kunci : Anak, ISPA, Merokok

\begin{abstract}
According to the World Health Organization (WHO) estimates the incidence of Acute Respiratory Infections (ARI) in developing countries with under-five mortality rates above 40 per 1000 live births. Cigarette smoke as one of the risks of ARI is a problem that is very difficult to minimize. The purpose of the study was to determine the relationship of smoking habits in the home with the incidence of ARI in children aged 0-5 years at the Bukit Sangkal Palembang Health Center in 2019. The research method used was a quantitative method with a cross sectional analytic approach. The population of all mothers who brought children aged 0-5 years to the Bukit Sangkal Palembang Health Center with a total sample of 30 respondents. The results showed the frequency distribution of respondents who were declared suffering from ARI as many as 11 respondents (36.7\%) and respondents whose family members smoked as many as 17 respondents (56.7\%). The results of statistical tests showed that there was a significant relationship between smoking habits and the incidence of ARI in infants in the Bukit Sangkal Palembang Health Center in 2019 with $p$ value $=0.007<\alpha(0.05)$ and $O R=17.143$. It is suggested that the research be expected that the puskesmas can improve health education routinely to the public about how to prevent and cope with ARI in the community.
\end{abstract}

Keywords : Children, ARI, Smoking 


\section{PENDAHULUAN}

Inspeksi Pernapasan Akut (ISPA) adalah penyakit saluran pernapasan atas dengan perhatian khusus pada radang paru (pneumonia). Infeksi Pernapasan Akut (ISPA) merupakan penyakit utama penyebab kematian bayi dan sering menempati urutan pertama angka kesakitan balita. Penanganan dini terhadap penyakit ISPA terbukti dapat menurunkan kematian (Irianto, 2014).

Hingga saat ini angka mortalitas ISPA yang berat masih sangat tinggi. Kematian seringkali disebabkan karena penderita datang untuk berobat dalam keadaan berat dan sering disertai penyulit-penyulit dan kurang gizi. Menurut World Health Organization (WHO) memperkirakan insidens Infeksi Saluran Pernapasan Akut (ISPA) di negara berkembang dengan angka kematian balita di atas 40 per 1000 kelahiran hidup adalah $15 \%$ - $20 \%$ pertahun pada golongan usia balita. (Purnama, 2016).

Di negara berkembang penyakit pneumonia merupakan $25 \%$ penyumbang kematian pada anak terutama pada bayi berusia kurang dari dua bulan. Dari survei kesehatan rumah tangga (SKRT) diketahui bahwa morbiditas pada bayi akibat pneumonia sebesar $42,4 \%$ dan pada balita sebesar 40,6\%. Sedangkan angka mortalitas pada bayi akibat pneumonia sebesar $24 \%$ dan pada balita sebesar $36 \%$. Penyakit ISPA sering terjadi pada anak-anak. Episode penyakit batuk pilek pada balita di Indonesia diperkirakan 3-6 kali pertahun (rata-rata 4 kali pertahun), artinya seorang balita ratarata mendapatkan serangan batuk pilek sebanyak 3-6 kali setahun. Dari hasil pengamatan epidemiologi dapat diketahui bahwa angka kesakitan di kota cenderung lebih besar daripada di desa. Hal ini mungkin disebabkan oleh tingkat kepadatan tempat tinggal dan pencemaran lingkungan di Kota yang lebih tinggi daripada di desa (Irianto, 2014).

Insidens menurut kelompok umur Balita diperkirakan 0,29 episode per anak/tahun di negara berkembang dan 0,05 episode per anak/tahun di negara maju. Ini menunjukkan bahwa terdapat 156 juta episode baru di dunia per tahun dimana 151 juta episode $(96,7 \%)$ terjadi di negara berkembang. Kasus terbanyak terjadi di India (43 juta), China (21 juta) dan Pa kistan (10 juta) dan Bangladesh, Indonesia, Nigeria masing-masing 6 juta (Kemenkes, 2015). ISPA merupakan penyakit yang sering terjadi pada anak. Dari semua kasus yang terjadi di masyarakat, 7-13\% kasus berat dan memerlukan perawatan rumah sakit. Episode batuk-pilek pada balita di Indonesia diperkirakan 2-3 kali per tahun. ISPA merupakan salah satu penyakit utama dengan kunjungan pasien yang tinggi di Puskesmas (40\%-60\%) dan rumah sakit (15\%-30\%) (Kemenkes, 2015).

Berdasarkan data Kementrian Kesehatan Republik Indonesia (Kemenkes RI) tahun 2017, angka kejadian pneumonia pada balita usia < 1 tahun sebanyak 149.944 orang dengan angka kematian sebanyak 398 orang. Sedangkan angka kejadian pneumonia pada balita usia 1-4 tahun sebanyak 297.487 orang dengan angka kematian sebanyak 953 orang. Sedangkan kejadian pneumonia di Provinsi Sumatera Selatan berdasarkan data Kemenkes RI tahun 2017, kejadian pneumonia pada balita usia $<1$ tahun sebanyak 4.224 orang dengan angka kematian sebanyak 3 orang. Sedangkan angka kejadian pneumonia pada balita usia 1-4 tahun sebanyak 8.114 orang dengan angka kematian sebanyak 3 orang (Kemenkes, 2018).

Berdasarkan data Dinas Kesehatan Kota Palembang, jumlah kasus ISPA pada balita tahun 2015 sebanyak 5.724 kasus, tahun 2016 sebanyak 5.198 kasus dan tahun 2017 sebanyak 5.783 kasus dari 160.211 balita. Kasus terbanyak terdapat pada kecamatan Sukarami sebanyak 560 kasus dan kasus ISPA terendah terdapat pada Kecamatan Sematang Borang sebanyak 140 kasus (Dinkes Kota Palembang, 2018).

Pencegah penularan ISPA dapat dilakukan dengan imunisasi, ada vaksin tiga jenis virus utama flu yang formulanya berganti tiap tahun untuk menghindari risiko virus kebal pada vaksin. Cara lain yang 
utama adalah menjaga daya tahan tubuh lewat perilaku hidup sehat, termasuk mengkonsumsi makanan bergizi seimbang dan cukup istirahat (Mardiah, 2017). Tingginya angka kejadian ISPA pada balita disebabkan oleh beberapa faktor, diantaranya adalah faktor instrinstik, faktor ekstrinsik. Faktor instrinsik meliputi umur, jenis kelamin, status gizi, status asi eklusif, status imunisasi. Sedangkan faktor ekstrinstik meliputi kondisi fisik lingkungan rumah, meliputi yang kepadatan hunian, polusi udara, tipe rumah, ventilasi, asap rokok, penggunaan bahan bakar, serta faktor perilaku baik pengetahuan dan sikap ibu (Andriani, 2014).

Asap rokok sebagai salah satu resiko timbulnya ISPA merupakan masalah yang sangat sulit untuk di minimalisir, sementara itu berdasarkan data Depkes RI, jumlah perokok dalam suatu keluarga cukup tinggi, dan orang yang berada di sekitar seorang perokok atau perokok pasif justru mempunyai resiko kesehatan yang lebih tinggi dibandingkan perokok aktif. Pusat Komunikasi Publik Sekretariat Jenderal Kementerian Kesehatan RI, memberitakan sebanyak 62 juta perempuan dan 30 juta laki-laki Indonesia menjadi perokok pasif di Indonesia, dan yang paling menyedihkan adalah anak-anak usia 0-4 tahun yang terpapar asap rokok berjumlah 11,4 juta anak. Rokok merupakan masalah yang kian menjerat anak, remaja dan wanita di Indonesia (Wijaya, 2014).

Berdasarkan hasil observasi awal yang peneliti lakukan di Puskesmas Bukit Sangkal Palembang, dari hasil wawancara mendalam terhadap 7 orang responden yang anaknya menderita ISPA didapatkan informasi bahwa dari 7 orang responden sebagian besar yaitu sebanyak 6 orang yang didalam rumahnya terdapat anggota keluarga yang merokok. Sehingga diperkirakan anak yang sering terpapar asap rokok yang berada didalam rumahnya dan mengganggu saluran pernapasannya hingga beresiko terkena penyakit ISPA.

Berdasarkan studi pendahuluan diatas maka peneliti tertarik untuk melakukan penelitian tentang "Hubungan Kebiasaan Merokok Di Dalam Rumah Dengan Kejadian ISPA Pada Anak Balita 0-5 Tahun Di Puskesmas Bukit Sangkal Palembang 2019".

\section{METODE PENELITIAN}

\section{Jenis Penelitian}

Pada penelitian ini metode yang digunakan adalah menggunakan kuantitatif dengan pendekatan analitik cross sectional

\section{Waktu dan Tempat Penelitian}

Penelitian ini dilaksanakan pada tanggal 8 April - 2 Mei 2019.

\section{Tempat Penelitian}

Penelitian ini dilaksanakan di Puskesmas Bukit Sangkal Palembang.

\section{Populasi Dan Sampel \\ Populasi}

Populasi pada penelitian ini adalah semua ibu yang membawa anak usia 0-5 tahun ke Puskesmas Bukit Sangkal Palembang saat dilakukan penelitian.

\section{Sampel}

Sampel penelitian ini adalah sebagian ibu yang membawa anak usia 0-5 tahun ke Puskesmas Bukit Sangkal Palembang saat dilakukan penelitian

\section{Teknik Pengambilan Sampel}

Pengambilan sampel pada penelitian ini dilakukan dengan cara non probability sampling menggunakan metode purposive sampling Responden tidak bersedia menjadi responden.

\section{Pengumpulan data}

1. Analisa Data Univariat

2. Analisa Bivariat

\section{Data dan Cara Pengumpulan Data \\ Data}

\section{Data primer}

Dalam penelitian ini data primer diperoleh secara langsung dengan cara 
melakukan pemeriksaan fisik terhadap anak dan memberikan pertanyaan langsung dalam bentuk kuesioner kepada ibu yang membawa balita ke Puskesmas Bukit Sangkal Palembang untuk mengetahui kebiasaan merokok dengan kejadian penyakit ISPA pada balita.

\section{Data Sekunder}

Data sekunder didapat dari data Puskesmas Bukit Sangkal Palembang, buku-buku sumber dan bahan internet yang berkaitan dengan topik penelitian.

\section{Cara Pengumpulan Data}

Teknik pengumpulan data pada penelitian ini diawali dengan melakukan studi pendahuluan di Puskesmas Bukit Sangkal Palembang terhadap anak umur 0-5 tahun yang menderita ISPA. Kemudian peneliti memilih responden yang akan dijadikan sampel dengan menggunakan teknik purposive sampling dengan terlebih dahulu meminta persetujuan responden menggunakan informed consent dan menjelaskan maksud dan tujuan penelitian.

$$
\text { Tahap selanjutnya peneliti }
$$

melakukan observasi dengan memeriksa keadaan fisik anak serta meminta responden untuk mengisi kuesioner. Setelah semua kuesioner terisi kemudian peneliti melakukan pengolahan data secara komputerisasi menggunakan program SPSS dengan uji chi square dan menarik kesimpulan dan saran dari hasil yang telah didapat.

\section{Teknik Analisis Data}

Metode analisis data yang digunakan dalam penelitian ini adalah analisis kuantitatif menggunakan program Statistical Product and Service Solution (SPSS) versi 19.

\section{HASL PENELITIAN DAN PEMBAHASAN}

HASIL PENELITIAN

Analisis Univariat

\section{Kejadian ISPA Pada Balita}

Tabel 4.1

Distribusi Responden Berdasarkan Kejadian ISPA Di Puskesmas Bukit Sangkal Palembang Tahun 2019

\begin{tabular}{|c|c|c|}
\hline Kejadian ISPA & Frekuensi & $\%$ \\
\hline $\mathrm{Ya}$ & 11 & 36,7 \\
\hline Tidak & 19 & 63,3 \\
\hline Jumlah & 30 & 100 \\
\hline
\end{tabular}

Tabel 4.2

Distribusi Responden Berdasarkan Kejadian ISPA Di Puskesmas Bukit Sangkal Palembang Tahun 2019

\begin{tabular}{rlcc}
\hline \multicolumn{2}{r}{ Kejadian ISPA } & Frekuensi & \% \\
\hline Ya & & & \\
a. & Ringan & 9 & 81,8 \\
b. & Sedang & 2 & 18,2 \\
c. & Berat & & \\
Tidak & & 19 & 63,3 \\
\hline \multicolumn{5}{r}{} & Jumlah & 30 & 100 \\
\hline
\end{tabular}

Pada tabel 4.2 diketahui bahwa distribusi frekuensi responden yang dinyatakan menderita ISPA sebanyak 11 responden terdiri dari 9 orang kategori ringan $(81,8 \%)$ dan 2 orrang kategori sedang $(18,2 \%)$ yang dinyatakan tidak menderita ISPA sebanyak 19 responden $(63,3 \%)$.

\section{Kebiasaan Merokok Di Dalam Rumah}

Tabel 4.3

Distribusi Responden Berdasarkan Kebiasaan Merokok Di Dalam Rumah Di Puskesmas Bukit Sangkal Palembang Tahun 2019

\begin{tabular}{|c|c|c|}
\hline $\begin{array}{c}\text { Kebiasaan Merokok } \\
\text { Di Dalam Rumah }\end{array}$ & Frekuensi & $\%$ \\
\hline $\mathrm{Ya}$ & 17 & 56,7 \\
\hline Tidak & 13 & 43,3 \\
\hline Jumlah & 30 & 100 \\
\hline
\end{tabular}

Pada tabel 4.3 diketahui bahwa distribusi frekuensi responden yang didalam rumahnya ada anggota keluarga yang merokok sebanyak 17 responden $(56,7 \%)$ dan responden yang didalam rumahnya tidak terdapat anggota keluarga yang merokok sebanyak 13 responden $(43,3 \%)$. 


\section{Analisis Bivariat}

\section{Hubungan Kebiasaan Merokok Di Dalam Rumah Dengan Kejadian ISPA Pada Balita}

\begin{tabular}{|c|c|c|c|c|c|c|c|c|}
\hline \multicolumn{9}{|c|}{$\begin{array}{c}\text { Tabel } 4.4 \\
\text { Hubungan Kebiasaan Merokok Di Dalam Rumah } \\
\text { dengan Kejadian ISPA Pada Balita di Puskesmas Bukit } \\
\text { Sangkal Palembang Tahun } 2019\end{array}$} \\
\hline \multirow{3}{*}{$\begin{array}{l}\text { Kebiasaan } \\
\text { Merokok } \\
\text { Didalam } \\
\text { Rumah }\end{array}$} & \multicolumn{4}{|c|}{$\begin{array}{c}\text { Kejadian ISPA } \\
\text { Pada Balita }\end{array}$} & \multirow{2}{*}{\multicolumn{2}{|c|}{$\underset{\mathbf{h}}{\mathbf{J u m l a}}$}} & \multirow{3}{*}{$\begin{array}{l}\text { p. } \\
\text { va } \\
\text { lu } \\
\mathbf{e}\end{array}$} & \multirow{3}{*}{ OR } \\
\hline & \multicolumn{2}{|c|}{ Ya } & \multicolumn{2}{|c|}{ Tidak } & & & & \\
\hline & $\mathbf{n}$ & $\%$ & $\mathrm{n}$ & $\%$ & $\mathbf{N}$ & $\%$ & & \\
\hline $\mathrm{Ya}$ & 10 & $\begin{array}{c}58 \\
8\end{array}$ & 7 & $\begin{array}{c}41, \\
2\end{array}$ & $\begin{array}{l}1 \\
7\end{array}$ & $\begin{array}{l}1 \\
0 \\
0\end{array}$ & $\begin{array}{l}0 \\
00\end{array}$ & $\begin{array}{c}17.14 \\
3\end{array}$ \\
\hline Tidak & 1 & 7,7 & 12 & $\begin{array}{c}92, \\
3\end{array}$ & $\begin{array}{l}1 \\
3\end{array}$ & $\begin{array}{l}1 \\
0 \\
0\end{array}$ & 7 & \\
\hline Jumlah & 11 & & 19 & & $\begin{array}{l}3 \\
0\end{array}$ & & & \\
\hline
\end{tabular}

Dari tabel 4.4 dapat diketahui bahwa dari 17 responden yang didalam rumahnya ada anggota keluarga yang merokok terdapat 10 responden $(58,8 \%)$ yang anak balitanya didiagnosa menderita ISPA dan dari 13 responden yang didalam rumahnya tidak terdapat anggota keluarga yang merokok terdapat 1 responden $(7,7 \%)$ yang anak balitanya didiagnosa tidak menderita ISPA.

Dari hasil uji Chi Square didapatkan P Value $=0,007<\alpha(0,05)$ hal ini menunjukkan ada hubungan yang bermakna antara kebiasaan merokok didalam rumah dengan kejadian ISPA pada balita di Puskesmas Bukit Sangkal Palembang Tahun 2019. Sedangkan nilai OR didapatkan sebesar 17,143 yang menunjukkan bahwa anak balita yang didalam rumahnya terdapat anggota keluarga yang merokok memiliki resiko 17,143 kali menderita ISPA dibandingkan dengan anak balita yang didalam rumahnya tidak terdapat anggota keluarga yang merokok.

Sehingga hipotesa yang menyatakan ada hubungan yang bermakna antara kebiasaan merokok didalam rumah dengan kejadian ISPA pada balita di Puskesmas Bukit Sangkal Palembang Tahun 2019 terbukti secara statistik.

\section{PEMBAHASAN}

Penelitian ini dilakukan di Puskesmas Bukit Sangkal Palembang pada tanggal 8 April - 2 Mei tahun 2019. Populasi yang diambil adalah semua ibu yang membawa balita berusia 0-5 tahun ke Puskesmas Bukit Sangkal Palembang dengan jumlah sampel yaitu sebanyak 30 sampel. Pengambilan sampel dilakukan dengan cara purposive sampling. Data yang dikumpulkan langsung dengan responden dengan observasi dan kuesioner sebagai alat bantu.

Selanjutnya data yang dikumpulkan diolah dan dilakukan analisis univariat dan bivariat. Pada analisis bivariat dilakukan uji statistik Chi square dengan sistem komputerisasi sehingga didapatkan nilai $P$ Value untuk melihat derajat kemaknaannya.

\section{Kejadian ISPA Pada Balita}

Infeksi saluran pernafasan akut (ISPA) adalah penyakit saluran pernafasan atas atau bawah, biasanya menular, yang dapat menimbulkan berbagai spektrum penyakit yang berkisar dari penyakit tanpa gejala atau infeksi ringan sampai penyakit yang parah dan mematikan, tergantung pada patogen penyebabnya seperti faktor lingkungan, dan faktor pejamu. (Masriadi, 2018).

Berdasarkan tabel 4.1 diketahui bahwa distribusi frekuensi responden yang dinyatakan menderita ISPA sebanyak 11 responden $(36,7 \%)$ dan responden yang dinyatakan tidak menderita ISPA sebanyak 19 responden $(63,3 \%)$.

Hasil penelitian ini sejalan dengan penelitian Milo (2015), yang berjudul hubungan kebiasaan merokok di dalam rumah dengan kejadian ISPA pada anak umur 1-5 tahun di Puskesmas Sario Kota Manado. Hasil penelitian didapatkan responden dengan Penyakit ISPA sebagian besar didapati responden dengan ISPA ringan yaitu 34 responden $(66,7 \%)$ dan responden dengan ISPA sedang sebanyak 17 responden $(33,3 \%)$.

Hasil penelitian ini juga sejalan dengan penelitian Rahmawati (2017) yang Jurnal Kesehatan dan Pembangunan, Vol. 9, No.18, Juli 2019 
berjudul hubungan antara perilaku merokok pada orang tua dengan kejadian infeksi saluran pernapasan akut (ISPA) pada anak balita di Puskesmas Porong. Hasil penelitian didapatkan sebagian besar anak mengalami kejadian ISPA tergolong sedang dengan besar $87,8 \%$. Sedangkan lainnya, sebesar $9,6 \%$ anak mengalami kejadian ISPA tergolong rendah dan 2,6\% anak mengalami kejadian ISPA tergolong tinggi.

Menurut Wahyuningsih (2017), menjelaskan berdasarkan data WHO, ISPA merupakan salah satu penyebab kematian tersering pada anak di negara yang sedang berkembang. Infeksi Saluran Pernafasan Akut ini menyebabkan empat dari 15 juta perkiraan kematian pada anak berusia di bawah 5 tahun pada setiap tahunnya dan sebanyak dua pertiga dari kematian tersebut terjadi pada bayi. Penyakit ISPA masih merupakan salah satu masalah kesehatan masyarakat yang utama. Tingkat polusi yang dihasilkan bahan bakar menggunakan kayu jauh lebih tinggi dibandingkan bahan bakar menggunakan gas. Sejumlah penelitian menunjukkan paparan polusi dalam ruangan meningkatkan risiko kejadian ISPA pada anak-anak. Selain berasal dari Asap pembakaran Bahan bakar Biomassa pemcemaran udara dalam rumah juga dapat bersal dari paparan asap rokok yang dihembuskan orang di sekitarnya terutama ayah dan ibunya.

\section{Kebiasaan Merokok}

Berdasarkan analisis univariat diketahui bahwa distribusi frekuensi responden yang didalam rumahnya ada anggota keluarga yang merokok sebanyak 17 responden $(56,7 \%)$ dan responden yang didalam rumahnya tidak terdapat anggota keluarga yang merokok sebanyak 13 responden $(43,3 \%)$.

Hasil penelitian ini sejalan dengan penelitian Milo (2015), yang berjudul hubungan kebiasaan merokok di dalam rumah dengan kejadian ISPA pada anak umur 1-5 tahun di Puskesmas Sario Kota Manado. Hasil penelitian didapatkan responden dengan kebiasaan merokok menunjukkan sebagian besar adalah responden dengan umur 17-34 tahun yaitu 40 responden $(78,4 \%)$.

Hasil penelitian ini juga sejalan dengan penelitian Rahmawati (2017) yang berjudul hubungan antara perilaku merokok pada orang tua dengan kejadian infeksi saluran pernapasan akut (ISPA) pada anak balita di Puskesmas Porong. Hasil penelitian didapatkan sebagian besar responden memiliki kebiasaan merokok yaitu sebesar $59,1 \%$ sedangkan $40,9 \%$ tidak merokok.

Hal ini sesuai dengan pernyataan Wijaya (2014), yang menyatakan bahwa asap rokok sebagai salah satu resiko timbulnya ISPA pada balita merupakan masalah yang sangat sulit untuk di minimalisir, sementara itu berdasarkan data Depkes RI, jumlah perokok dalam suatu keluarga cukup tinggi, dan orang yang berada di sekitar seorang perokok atau perokok pasif justru mempunyai resiko kesehatan yang lebih tinggi dibandingkan perokok aktif. Pusat Komunikasi Publik Sekretariat Jenderal Kementerian Kesehatan RI, memberitakan sebanyak 62 juta perempuan dan 30 juta laki-laki Indonesia menjadi perokok pasif di Indonesia, dan yang paling menyedihkan adalah anak-anak usia 0-4 tahun yang terpapar asap rokok berjumlah 11,4 juta anak.

\section{Hubungan Kebiasaan Merokok Di Dalam Rumah dengan Kejadian ISPA Pada Balita}

Berdasarkan hasil analisis bivariat diketahui bahwa dari 17 responden yang didalam rumahnya ada anggota keluarga yang merokok terdapat 10 responden $(58,8 \%)$ yang anak balitanya didiagnosa menderita ISPA dan dari 13 responden yang didalam rumahnya tidak terdapat anggota keluarga yang merokok terdapat 1 responden $(7,7 \%)$ yang anak balitanya didiagnosa tidak menderita ISPA.

Dari hasil uji Chi Square didapatkan P Value $=0,007<\alpha(0,05)$ hal ini menunjukkan ada hubungan yang bermakna antara kebiasaan merokok didalam rumah dengan kejadian ISPA pada balita di Puskesmas Bukit Sangkal Palembang Tahun 
2019. Sedangkan nilai OR didapatkan sebesar 17,143 yang menunjukkan bahwa anak balita yang didalam rumahnya terdapat anggota keluarga yang merokok memiliki resiko 17,143 kali menderita ISPA dibandingkan dengan anak balita yang didalam rumahnya tidak terdapat anggota keluarga yang merokok. Sehingga hipotesa yang menyatakan ada hubungan yang bermakna antara kebiasaan merokok didalam rumah dengan kejadian ISPA pada balita di Puskesmas Bukit Sangkal Palembang Tahun 2019 terbukti secara statistik.

Hasil penelitian ini sejalan dengan penelitian Milo (2015), yang berjudul hubungan kebiasaan merokok di dalam rumah dengan kejadian ISPA pada anak umur 1-5 tahun di Puskesmas Sario Kota Manado. Berdasarkan hasil uji statistik didapatkan nilai $p$ value 0,002 dengan demikian $p$ value $<0,05$ dapat disimpulkan bahwa Ho ditolak dan Ha diterima. Dengan demikian dapat dikatakan bahwa ada hubungan antara kebiasaan merokok di dalam rumah dengan kejadian ISPA pada anak.

Hasil penelitian ini juga sejalan dengan hasil penelitian Wardani (2014), yang berjudul hubungan antara paparan asap rokok dengan kejadian Infeksi Saluran Pernapasan Akut (Ispa) Pada Balita Di Desa Pucung Rejo Kabupaten Magelang Tahun 2014. Berdasarkan uji statistik menggunakan computerisasi didapatkan hasil nilai $p$-value $0,007<0,05$ sehingga menunjukkan bahwa Ho ditolak dan $\mathrm{Ha}$ diterima yang menunjukkan bahwa ada hubungan yang bermakna secara statistik

Hal sesuai dengan pernyataan Wijaya (2014), yang menyatakan bahwa asap rokok dari orang tua atau penghuni rumah yang satu atap dengan balita merupakan bahan pencemaran dalam ruang tempat tinggal yang serius serta akan menambah resiko kesakitan dari bahan toksik pada anak-anak. Paparan yang teru smenerus akan menimbulkan gangguan pernapasan terutama memperberat timbulnya infeksi saluran pernafasan akut
(ISPA) dan gangguan paru-paru pada saat dewasa. Semakin banyak rokok yang dihisap oleh keluarga semakin besar memberikan resiko terhadap kejadian ISPA, khususnya apabila merokok dilakukan oleh ibu bayi.

Hal serupa dinyatakan Rohim (2014), yang menyatakan bahwa keluarga yang didalamnya terdapat salah satu anggota keluarga yang menjadi perokok aktif, hal ini dapat mengganggu perokok pasif yaitu anggota keluarga yang tidak merokok namun terkena asap rokok, terutama balitabalita yang sering terkena dampaknya. Karena perokok pasif lebih sering berada di dekat keluarga yang mempunyai kebiasaan merokok sehingga udara yang dihirupnya sudah terkontaminasi oleh asap rokok yang mengakibatkan radang tenggorokan, penyakit asma dan penyakit pernafasan lainya. Untuk menghindari hal tersebut maka diperlukan kesadaran diri dan saling mengerti bagi keluarga yang mempunyai kebiasaan merokok untuk tidak merokok di dalam rumah dan bahkan dilingkungan rumah hal ini bertujuan untuk meminimalisir terjadinya penyakit pernapasan yang disebabkan oleh asap rokok.

$$
\text { Selain itu Rohim (2014), }
$$
menambahkan bahwa paparan asap rokok berpengaruh terhadap kejadian ISPA pada balita, dimana balita yang terpapar asap rokok berisiko lebih besar untuk terkena ISPA dibanding balita yang tidak terpapar asap rokok. Asap rokok yang dihisap, baik oleh perokok aktif maupun perokok pasif akan menyebabkan fungsi ciliary terganggu, volume lendir meningkat, humoral terhadap antigen diubah, serta kuantitatif dan kualitatif perubahan dalam komponen selular terjadi. Beberapa perubahan dalam mekanisme pertahanan tidak akan kembali normal sebelum terbebas dari paparan asap rokok. Sehingga selama penderita ISPA masih mendapatkan paparan asap rokok, proses pertahanan tubuh terhadap infeksi tetap akan terganggu dan akan memperlama waktu yang dibutuhkan untuk penyembuhannya. 
Hasil penelitian ini juga sesuai dengan pernyataan Aprilioza (2016) yang menyatakan bahwa rokok menjadi salah satu faktor risiko penyakit ISPA karena rokok mengganggu fungsi pertahanan paru, melalui gangguan fungsi silia dan kerja sel makrofag alveolus. Kedua mekanisme tersebut menyebabkan mikroorganisme yang masuk ke dalam saluran napas dengan mudah masuk mencapai paru-paru lalu merusak jaringan paru dengan mengeluarkan toksin sehingga agen infeksius masuk ke dalam saluran pernapasan, kemudian melakukan adhesi pada dinding bronkus dan bronkiolus, lalu bermultiplikasi, dan timbul pemicu untuk terjadi inflamasi dalam tubuh. Pada saat timbul reaksi inflamasi, kantung udara alveoli akan terisi dengan cairan eksudat yang banyak mengandung protein, sel inflamasi seperti neutrofil fase akut, kemudian makrofag dan limfosit pada fase kronik. Akibat kantung udara alveoli yang terisi eksudat, maka proses difusi oksigen dan karbondioksida menjadi terganggu, sehingga pasien yang mengidap penyakit ini akan mengalami hipoksemia, dan hiperkapnia.

Berdasarkan hasil penelitian dan pembahasan diatas peneliti berasumsi bahwa ada hubungan kebiasaan merokok di dalam rumah dengan kejadian ISPA pada balita. Hal ini karena asap yang berasal dari rokok mengandung berbagai macam racun yang dapat berbahaya jika terhirup oleh bayi dan balita yang dapat mengganggu sistem pernafasannya salah satunya penyakit ISPA.

\section{KESIMPULAN DAN SARAN}

\section{Kesimpulan}

Berdasarkan hasil penelitian yang telah dilakukan di Puskesmas Bukit Sangkal Palembang, dapat disimpulkan sebagai berikut:

1. Distribusi frekuensi responden yang dinyatakan menderita ISPA sebanyak 11 responden $(36,7 \%)$ dan responden yang dinyatakan tidak menderita ISPA sebanyak 19 responden $(63,3 \%)$.

2. Distribusi frekuensi responden yang anggota keluarganya merokok sebanyak 17 responden $(56,7 \%)$ dan responden anggota keluarganya tidak merokok sebanyak 13 responden $(43,3 \%)$

3. Ada hubungan yang bermakna antara kebiasaan merokok dengan kejadian ISPA pada balita di Puskesmas Bukit Sangkal Palembang Tahun 2019 dengan $\mathrm{p}$ value $=0,007<\alpha(0,05)$ dan nilai $\mathrm{OR}$ $=17,143$

\section{Saran}

\section{Bagi Stikes Mitra Adiguna Palembang}

\begin{abstract}
Diharapkan dapat melengkapi sumber-sumber bacaan yang ada di Perpustakaan Stikes Mitra Adiguna Palembang khususnya teori-teori tentang ISPA baik dari buku maupun dari majalah sehingga dapat membantu bagi mahasiswa yang akan melakukan penelitian tentang ISPA.
\end{abstract}

\section{Bagi Puskesmas Bukit Sangkal Palembang}

Diharapkan pihak puskesmas dapat meningkatkan penyuluhan kesehatan secara rutin kepada masyarakat tentang bagaimana cara mencegah dan menanggulangi penyakit ISPA di masyarakat, serta menjelaskan kepada masyarakat tentang bahaya merokok terhadap kesehatan seluruh anggota keluarga serta pentingnya melakukan imunisasi pada bayi agar terhindar dari berbagai penyakit khususnya penyakit ISPA.

\section{Bagi Peneliti Selanjutnya}

Diharapkan peneliti selanjutnya dapat melakukan penelitian serupa dengan menggunakan variabel dan desain penelitian yang berbeda sehingga diharapkan penelitian tentang ISPA dapat lebih bervariasi. 


\section{DAFTAR PUSTAKA}

Ahyanti. 2013. Hubungan merokok Dengan kejadian ISPA Pada Mahasiswa Politeknik Kesehatan Kementerian Kesehatan Tanjungkarang. Jurnal Kesehatan Masyarakat, Maret 2013 - September 2013, Vol. 7, No. 2

Andriani, Marlina. 2014. Hubungan pengetahuan dan sikap ibu terhadap kejadian ISPA pada balita di Wilayah Kerja Puskesmas Tigo Baleh Bukit Tinggi. Jurnal STIKES Yarsi Sumatera Barat Bukit Tinggi

Andriyani, Ratih. 2015. Bahaya Merokok. Jakarta : PT. Sarana Bangun Pustaka

Aprilioza, Almer. 2016. Hubungan kebiasaan merokok pada orang tua di rumah dengan kejadian pneumonia pada balita di Wilayah Kerja Puskesmas Plered. Jurnal Fakultas Kedokteran Universitas Islam Bandung.

Dinas Kesehatan Kota Palembang. 2018. Profil Kesehatan Kota Palembang. http://www.dinkes.go.id, diakses 15 Februari 2019

Fitria. 2017. Pencegahan ISPA. http://www.wordpress.com, diakses 20 Februari 2019

Hartono R dan Dwi Rahmawati. 2016. ISPA gangguan pernafasan pada anak. Yogyakarta : Nuha Medika

Idea. 2017. Tahapan tumbuh kembang bayi dan balita. http://www.helosehat.com, diakses 23 Januari 2019

Irianto, Koes. 2014. Epidemiologi penyakit menular dan tidak menular panduan klinis. Bandung : Alfabeta
Jahja,
$\begin{gathered}\text { Yudrik. } 2015 . \\ \text { perkembangan. } \\ \text { Prenadamedia group }\end{gathered}$

Kementrian Kesehatan Republik Indonesia. 2015. Buku Bagan Manajemen Terpadu Balita Sakit (MTBS). http://www.kemenkes.go.id, diakses 15 Februari 2019

Kementrian Kesehatan Republik Indonesia. 2018. Profil Kesehatan Republik Indonesia.

http://www.kemenkes.go.id, diakses 15 Februari 2019

Mahendrayasa. 2018. Hubungan Antara Kondisi Fisik Rumah Dengan Kejadian Infeksi Saluran Pernafasan Atas Pada Balita Di Surabaya. Jurnal Volume 6 Nomor 3 (2018) 227-235

Mardiah. 2016. Pencegahan Penularan Infeksi Saluran Pernafasan Akut Dan Perawatannya Pada Balita Dirumah Di Kabupaten Pangandaran. Fakultas Kesehatan Masyarakat Universitas Sam Ratulangi Manado

Masriadi. 2018. Epidemiologi penyakit menular. Depok : PT. Raja Grafindo Persada

Milo. 2015. Hubungan kebiasaan merokok di dalam rumah dengan kejadian ISPA pada anak umur 1-5 tahun di Puskesmas Sario Kota Manado. Journal Keperawatan (e-Kp) Volume 3 Nomor 2, Mei2015

Notoatmodjo, Soekidjo. 2012. Metode penelitian kesehatan. Jakarta : PT Rineka Cipta

Padila. 2013. Asuhan Keperawatan Penyakit Dalam. Yogyakarta: Nuha Medika 
Purnama, Sang Gede. 2016. Buku ajar penyakit berbasis lingkungan. Jakarta

Putra, Dony Setiawan. 2014. Keperawatan anak dan tumbuh kembang (pengkajian dan pengukuran). Yogyakarta : Nuhamedika

Rahmawati. 2017. Hubungan antara perilaku merokok pada orang tua dengan kejadian infeksi saluran pernapasan akut (ISPA) pada anak balita di Puskesmas Porong. Jurnal Fakultas Ilmu Keolahragaan Univesitas Negeri Malang

Rasmaliah. 2017. Infeksi Saluran Pernafasan Akut (ISPA) Dan Penanggulangannya. Jurnal. Fakultas Kesehatan Masyarakat Universtias Sumatera Utara.

Rohim, Moh. Miftahur. 2014. Hubungan merokok anggota keluarga dengan kejadian infeksi saluran pernafasan akut (ISPA) pada balita di Wilayah Kerja Puskesmas Paciran Kabupaten Lamongan. Jurnal Keperawatan STIKES Majapahit Mojokerto.

Wardani. 2014. Hubungan Antara Paparan Asap Rokok Dengan Kejadian Infeksi Saluran Pernapasan Akut (Ispa) Pada Balita Di Desa Pucung Rejo Kabupaten Magelang Tahun 2014. Jurnal Kebidanan Vol.5 No. 10. April 2016

Wijaya. 2014. Hubungan Kebiasaan Merokok, Imunisasi Dengan Kejadian Penyakit Pneumonia Pada Balita Di Puskesmas Pabuaran Tumpeng Kota Tangerang. Forum Ilmiah Volume 11 Nomor 3. Universitas Esa Unggul Jakarta. Puskesmas Bukit Sangkal Palembang. 2019. Jumlah penderita ISPA pada balita tahun 2016-2018. 